\title{
Measuring the Efficiency of BAZNAS in Managing Zakat Funds with Stochastic Frontier Approach Analysis, 2002-2016
}

\author{
Risanda A. Budiantoro, Faishol Luthfi, and Sri Herianingrum \\ Airlangga University
}

\begin{abstract}
This study aims to measure the technical efficiency and identify factors that cause technical inefficiency of Badan Amil Zakat Nasional (BAZNAS) in managing zakat funds on receipt and the distribution of zakat funds. The data used were time series data from 2002 to 2016. The input variables used were total assets and operational costs, while the output variables were the receipt of zakat funds and the distribution of zakat funds. Using stochastic frontier analysis, this study has successfully identified that total assets and operational costs had a positive and significant effect on the receipt of zakat funds. The same results also demonstrated that the operational costs for the distribution of zakat funds had a positive and significant effect. The results for total assets on distribution of zakat funds were positive but not significant. Overall, the technical efficiency regarding the receipt of BAZNAS zakat funds was found to be 94.98 percent, which means that there is 5.02 percent remaining that could still be optimized, while technical efficiency regarding the distribution of BAZNAS zakat funds was found to be 70.99 percent, leaving 29.01 percent that could still be optimized.
\end{abstract}

Keywords: Badan Amil Zakat Nasional (BAZNAS), Stochastic Frontier Analysis, Technical Efficiency

\section{INTRODUCTION}

\section{Background}

Zakat is one of the main aspects of Islam, being the third pillar of Islam. The proposition for zakat is found in the Q.S. At Tawbah (9: 103):

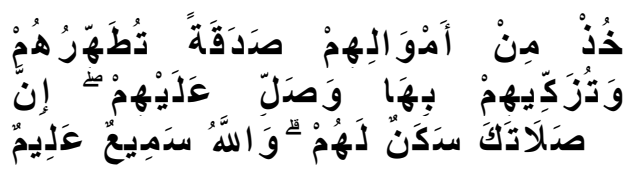

Meaning: "Take, [O, Muhammad], from their wealth a charity by which you purify them and cause them increase, and invoke [Allah's blessings] upon them. Indeed, your invocations are reassurance for them. And Allah is Hearing and Knowing."

Al Parisi (2017) explains that zakat can stimulate the economy, resulting in the accumulation of new investments that will encourage increased production for the economic cycle of a region. Even at the macro level, zakat will be able to increase aggregate demand due to increasing the purchasing power of society with regards to goods and services. When zakat is managed properly, it may be implicated in the emergence of new jobs, meaning that a certain amount of unemployment will be absorbed.

Outlook Zakat Indonesia 2017, published by the Center for Strategic Studies of Badan Amil Zakat Nasional (PUSKAS BAZNAS), shows an annual 
increase in zakat funds collected. The cause of the increase in zakat funds is the increased participation of institutions and companies to pay zakat. The optimal management of zakat will decrease the poverty levels. The relationship between zakat funds and the poor are disproportional: Zakat funds collected annually have increased while the number of poor people still fluctuates. This comparison shows that zakat funds are still not optimally managed (Nurhasanah \& Lubis, 2017).

BAZNAS is a zakat organization that was officially formed by the government. BAZNAS plays an important role in the framework of the collection and distribution of zakat funds. Due to this important role of BAZNAS, therefore, the performance efficiency of BAZNAS should be well-managed, especially in terms of the collection and distribution of zakat funds.

\section{Limitations of the Research}

Based on the above background, it is necessary to set boundaries for the problem so that the following discussion is focused and not blurred or unnecessarily expanded. The problems to be focused on are as follows:

1. The object of this study only concerns BAZNAS, with the research period range 2002-2016.

2. The data used is the BAZNAS Annual Financial Report, 2002-2016.

3. The analysis used is the parametric Stochastic Frontier Analysis (SFA) method, with a production approach.

\section{Formulation of the problem}

BAZNAS is the organization that manage zakat funds that was officially and solely formed by the government. Zakat potential in Indonesia has not been properly maximized, which means that it has become a challenge as well as an opportunity for BAZNAS to continuously improve the quality of their performance so as to collect and distribute zakat funds efficiently. Therefore, appropriate strategies are needed to improve the performance of BAZNAS in its role as a zakat management organization. To assess the performance of BAZNAS in the reception and distribution of zakat, one of the approaches that can be used is an analysis of efficiency. Based on these issues, this study will analyze what variables are expected to affect the efficiency of BAZNAS in the reception and distribution of zakat funds so that in the future, BAZNAS operations regarding the management of zakat funds can be more efficient. Based on the above problem formulation, the formulated research questions are as follows:

1. What effect do BAZNAS operating expenses and other assets have on the increase or decrease of zakat funds, for the period 2002-2016?

2. Regarding the receipt and distribution of zakat, does BAZNAS already operate efficiently based on parametric methods, for the period 2002-2016?

3. What are the technical efficiency scores of BAZNAS regarding the receipt and distribution of zakat funds based on parametric methods, for the period 2002-2016?

\section{Research Hypothesis}

A hypothesis is a research statement that is tested for its truth. The research hypotheses for the observation period 2002-2016 are:

1. Operating expenses are expected to have an effect on the receipt and distribution of BAZNAS zakat funds, for the period 2002-2016.

2. Total assets have a positive effect on the receipt and distribution of BAZNAS zakat funds, for the period 2002-2016. 


\section{Research Objectives}

The purpose of this study is to:

1. Understand the effect of BAZNAS operating expenses and other assets on the increase or decrease the receipt and distribution of zakat funds on BAZNAS, for the period 2002-2016.

2. Understand BAZNAS's level of efficiency regarding the reception and distribution of zakat based on parametric methods, for the period 2002-2016.

3. Understand the technical efficiency score of BAZNAS regarding the receipt and distribution of zakat funds based on a parametric method, for the period 2002-2016.

\section{LITERATURE REVIEW}

\section{Zakat}

Zakat is one of the important aspects of Islamic teachings. Beik (2009) explains that etymologically, the word 'zakat' has various meanings that involve developing (an-namaa), sanctifying (at-thaharatu), and blessing (albarakatu). Terminologically, zakat means the removal of certain property with certain conditions in order to be given to a certain group (mustahik) with certain requirements as well. Hafidhuddin (2002) and Beik (2009) have stated that zakat is the only form of worship that is managed by a specialized officer, as stated explicitly in Q.S. At-Taubah verse 60. Management of zakat through amil institutions has several advantages, including: (i) ensuring it is more in line with the guidance of sharia, shirah nabawiyyah and shirah of companions and later generations; (ii) guaranteeing the certainty and discipline of zakat payers; (iii) avoiding feelings of inferiority on the part of the mustahik if they deal directly with muzakki; (iv) achieving the efficiency and effectiveness of the management and utilization of zakat; and (v) as da'wah of Islam in the spirit of Islamic government. Meanwhile, al-Qardhawi (as cited in Beik, 2009) said that the fundamental purpose of zakat worship is to solve various social problems such as unemployment and poverty, amongst others. The zakat distribution system is a solution to these problems through the provision of assistance to the poor regardless of skin color, ethnicity, or other worldly attributes.

\section{Badan Amil Zakat Nasional (BAZNAS)}

Badan Amil Zakat Nasional (BAZNAS) is a non-structural institution established by Act No. 23 of 2011 on Zakat Management. The formation of BAZNAS was first established by Presidential Decree No. 8 of 2001 on the National Board of Zakat as mandated by Act No. 38 of 1999 on Zakat Management, which prevailed at that time. After the regulatory changes, BAZNAS became a non-structural government institution that is independent and responsible to the President through the Minister of Religious Affairs. BAZNAS is one of the few non-structural institutions that contributes to the state in the form of social welfare and poverty reduction through the management of zakat funds. BAZNAS receives financial assistance from the state budget in accordance with the law, but the benefits provided to the state and nation via BAZNAS is greater. Associated with the mandate of the 1945 Constitution Article 34 that "the poor and the neglected children are kept by the state," BAZNAS's role strongly supports the state's responsibility. BAZNAS acts as a provider of social security assistance for the poor. The presence of such institutions supports the task of the state to develop prosperity for society, thus it is naturally supported by the government. BAZNAS's role and contribution to society, especially Muslims, can be measured not only quantitatively but also qualitatively, especially the role of BAZNAS in 
disseminating the values of zakat to society. These values include faith and devotion to Allah SWT, work ethic in the finding for halal and thayib sustenance, and the values of zakat associated with the development of human character (i.e. character building as human beings who provide benefits for others).

\section{Theory of Efficiency}

Efficiency is a measure of effectiveness that is produced through a minimization of time, effort, and skill wasted (Archer, 2010 , p. 1). This is similar to Silkman (1986), who describes efficiency as the ability to accomplish work correctly or in a mathematical framework, defined as the calculation of the ratio of output and input or the amount of output produced from an input used. As practiced by companies in general, efficiency can also be applied to BAZNAS as a benchmark for its performance, such as allocation, and technical or total efficiency. In this case, efficiency is always associated with the existence of input and output variables; therefore, efficiency is defined as an inputoutput ratio. There are three factors that contribute to efficiency, among others, as noted by Permono and Darmawan (2000), such as: (1) If using the same input can produce a greater output; (2) If using smaller inputs can produce the same output; (3) If using greater input can result in larger percentage of output

According to Bauer, Berger, Ferrier, \& Humphrey (1998), efficiency is divided into two areas, namely :

1. Technical efficiency (microeconomic context)

This is where there is a technical relationship between the input and output variables used in the production process. Using the technical efficiency of the company is expected to produce the maximum output on available inputs used.
2 Economic efficiency (macroeconomic context)

In macroeconomics, the concept of economic efficiency has a wider coverage than the concept of technical efficiency. Here, companies must be able to determine the level of inputs and outputs used to achieve and optimize the economic condition (cost minimization or profit maximization).

\section{Previous Research}

Dong, Hamilton, and Tippett (2014) conducted a study on the efficiency of the banking sector in China by using SFA and DEA in the period 1994-2007. The input variables used were total loans, total manpower capital, and working hours, while the output variables used were total financing, acceptance of other assets, and non-interest income. The results showed that the use of SFA and DFA is highly recommended to determine the level of efficiency because it produces more complete data and is reliable in the determination of bank performance.

Nashihina and Harahap (2014) conducted a study on the efficiency of Islamic rural banks in Indonesia in the period January 2009 to December 2012 by comparing the production function approach (SFA) and the approach of financial ratios which using ROA. The results showed that Islamic rural banks generally operated efficiently, with an efficiency score of more than 90 percent. Efficiency based on financial ratios also demonstrated the same thing, which confirmed the findings of the production function approach.

Zuhroh, Ismail, and Maskie (2015) also examined the level of efficiency of Islamic banking in Indonesia (three Islamic banks and 19 conventional banks), using the SFA method for the period 2004-2010. The input variables used were assets and equity while the output variable used was NPL (Non-Performing Loan). The results 
demonstrated technically more efficient Islamic banks but that the average of the efficiency costs was still far below that of conventional banks. This suggests that the cause of the inefficiency of Islamic banks is an inefficient allocation of costs.

\section{RESEARCH METHODOLOGY}

\section{Research Model}

Based on previous studies and with adjustments that are considered to provide expected results to explain the efficiency of BAZNAS in the receipt and distribution of zakat funds, this research used a parametric method of Stochastic Frontiers Analysis (SFA) based on production function. The determination of input and output variables used in this study involved the production approach that considers the function of BAZNAS in managing cost to produce the efficient receipt and distribution of zakat funds. The input variables used were operating expenses and total assets, while the output variables used were the receipt and distribution of zakat. The general form of the SFA method with the production function was written according to the Cobb-Douglas production function, shown in Equation $i$ :

$$
\ln \left(\mathrm{Q}_{\mathrm{n}}\right)=\propto+\beta_{1} \ln \left(\mathrm{P}_{1}\right)+\beta_{2} \ln \left(\mathrm{P}_{2}\right)+\epsilon_{\mathrm{t}}
$$

By entering the input and output into the Cobb-Douglas production function, the equations were rewritten as Equations $i$ and iii below:

$$
\begin{gathered}
\ln \left(\mathrm{Q}_{1}\right)=\propto+\beta_{1} \ln \left(\mathrm{P}_{1}\right)+\beta_{2} \ln \left(\mathrm{P}_{2}\right)+ \\
\mathrm{U}_{\mathrm{t}}-\mathrm{V}_{\mathrm{t}} \\
\ln \left(\mathrm{Q}_{2}\right)=\propto+\underset{1}{\beta_{1} \ln \left(\mathrm{P}_{1}\right)+\beta_{2} \ln \left(\mathrm{P}_{2}\right)+} \\
\mathrm{U}_{\mathrm{t}}-\mathrm{V}_{\mathrm{t}}
\end{gathered}
$$

Where:

$$
\begin{aligned}
\mathrm{Q}_{1}= & \text { Receipt of zakat fund } \\
\mathrm{Q}_{2}= & \text { Distribution of zakat fund } \\
\mathrm{P}_{1}= & \text { Operating expenses } \\
\mathrm{P}_{2}= & \text { Total assets } \\
\mathrm{U}_{\mathrm{t}}= & \text { Random factors that can be } \\
& \text { controlled (inefficiency) } \\
\mathrm{V}_{\mathrm{t}}= & \text { Random factors that cannot be } \\
& \text { controlled }
\end{aligned}
$$

From equations $i i$ and $i i i$ above, then, $\mathrm{P}_{1}$ and $\mathrm{P}_{2}$ indicated the input variables used in BAZNAS for a certain period in this study, while $\mathrm{Q}_{1}$ and $\mathrm{Q}_{2}$ indicated the quantity of output used in BAZNAS for a certain period in this study.

\section{Output Variables}

This study used two output variables, namely the receipt of zakat funds and the distribution of zakat funds.

a. Receipt of Zakat Funds

The receipt of zakat is the total of the zakat funds that were collected from muzakki within a certain period. Receipt of zakat is the sum of zakat trade, zakat maal, and profit sharing on the placement of zakat funds. The total amount of zakat receipts was obtained from the annual financial statements on reports of changes in funds that were published annually by BAZNAS during the period of observation.

b. Distribution of Zakat Funds

The distribution of zakat funds involves a number of zakat funds distributed to mustahik at certain periods both for empowerment program cash disbursement. The amount of zakat distribution was obtained from the annual financial statements at the statement of changes in funds that were published annually by BAZNAS during the period of observation. 


\section{Input Variables}

This study used two output variables, namely operating expenses and total assets.

\section{a. Operating Expenses}

Operating expenses are direct costs that are used for the operational needs of a company. Based on the study object used (BAZNAS), this included the operating expenses of all expenses incurred for purposes that support the management of ZISWAF. The amount of operating expenses was obtained from cash flow statement in annual report that was published annually by BAZNAS during the period of observation.

\section{b. Total Assets}

The total assets were all assets owned by BAZNAS: current assets, fixed assets, and assets under management. The total assets were obtained from the annual financial statements on the statement of financial position published annually by BAZNAS during the period of observation.

\section{Types and Sources of Data}

The object of this study was the Badan Amil Zakat Nasional (BAZNAS), which remains the official and the only institution formed by the government to manage ZISWAF. The data used is secondary data obtained from financial statements published by BAZNAS from 2002 to 2016 (time series data) and other literature related to the efficiency of the national zakat fund managers.

The population in this research consisted of zakat management organizations, both government and private. In Indonesia ${ }_{2}$ the management of zakat formed by the government is managed by BAZ (Badan Amil Zakat), with BAZNAS as the central coordinator, while the private sector is managed by
LAZ (Lembaga Amil Zakat). The sample used in this research related only to BAZNAS.

\section{Analysis Tools}

In this study, the authors used time series data analysis with tools such as Microsoft Excel for data processing, E-Views 6 to determine the estimation modeling, and Frontier 4.1 to determine the value of efficiency in the receipt and distribution of zakat funds.

\section{Test Criteria Statistics}

a. Group of Variables Significance Test (Test Statistic F)

By using the F test, it can determine the influence of all independent variables toward the dependent variable. The Ftest calculation can be carried out by comparing the value of the F-statistic with the F-table at $\alpha$ or with the statistical probability of the F-statistic at $\alpha$ (significance level of 5 percent).

1. If the F-statistic $>$ F-table on $\alpha$ or prob (F-statistic) $<\alpha(0.05)$, then $\mathrm{H}_{0}$ is rejected (and $\mathrm{H}_{1}$ is accepted). That is, the independent variables have a jointly significant effect on the dependent variable.

2. If the F-statistic $<$ F-table at $\alpha$ or prob (F-statistic) $>\alpha(0.05)$, then $\mathrm{H}_{0}$ is accepted. That is, the independent variables jointly do not have a significant effect on the dependent variable.

b. Individual Significance Test (Test Statistic T)

This is testing to determine the influence of each independent variable can explain the dependent variable.

- If the $\mathrm{t}$-statistic $>\mathrm{t}$-table, then $\mathrm{H}_{0}$ is rejected or $\mathrm{H}_{1}$ is accepted. This means that independent variables have a partially significant effect on the dependent variable. 
- If the t-statistic $>$ t-table, then $\mathrm{H}_{0}$ is accepted and $\mathrm{H}_{1}$ is rejected. This means that the independent variables have a partially not significant effect on the dependent variable.

c. The Coefficient of Determination $\left(\mathrm{r}^{2}\right)$ The level of goodness of fit of the regression line corresponding to the data was used to determine the suitability of a sample regression line with the data. The value of $r^{2}$ will always be between 0 and 1 . The closer to 1 , the greater the ability of independent variables to explain the behavior of the dependent variable. So, the value of $r^{2}$ provides information on the proportion of variation of the dependent variable described by the independent variables, thus providing an overall measure of the variation of the variables affecting the variation of the other variables.
Stochastic Frontier Analysis (SFA) Test

After the regression equation was determined, the measurement of operational efficiency of BAZNAS regarding the management of zakat funds using the SFA method was carried out, using the Frontier 4.1 program. The results of efficiency values appeared in the form of scores in the range $0-1$. This means that SFA scores (technical efficiency) close to one demonstrated a greater level of efficiency on the part of BAZNAS in managing zakat funds.

\section{DISCUSSION}

\section{Descriptive Analysis}

Before the regression analysis, the authors conducted a descriptive statistical analysis. Descriptive statistical analysis is used to determine the overview of the data. Table 1 shows the results of descriptive statistical analysis on the variables in this research model.

Table 1 Descriptive Statistics Analysis Results

\begin{tabular}{|c|c|c|c|c|}
\hline Variable * & $\begin{array}{c}\text { Receipt of } \\
\text { Zakat Funds }\end{array}$ & $\begin{array}{l}\text { Distribution of } \\
\text { Zakat Funds }\end{array}$ & $\begin{array}{l}\text { Operating } \\
\text { Expenses }\end{array}$ & Total Asset \\
\hline Mean & $3.01 \mathrm{E}+10$ & $2.43 \mathrm{E}+10$ & $7.67 \mathrm{E}+09$ & $2.53 E+10$ \\
\hline Median & $1.94 \mathrm{E}+10$ & $1.40 \mathrm{E}+10$ & $3.40 \mathrm{E}+09$ & $2.06 \mathrm{E}+10$ \\
\hline Maximum & $9.76 \mathrm{E}+10$ & $6.77 \mathrm{E}+10$ & $2.90 \mathrm{E}+10$ & $9.28 \mathrm{E}+10$ \\
\hline Minimum & $2.96 \mathrm{E}+08$ & 99895146 & $1.51 \mathrm{E}+08$ & $4.73 E+08$ \\
\hline Std. Dev. & $3.18 \mathrm{E}+10$ & $2.57 \mathrm{E}+10$ & $8.35 E+09$ & $2.41 E+10$ \\
\hline Skewness & 0.916071 & 0.701878 & 1.245945 & 1.641425 \\
\hline Kurtosis & 2.565915 & 1.964390 & 3.805375 & 5.294350 \\
\hline Jarque-Bera & 2.215733 & 1.901888 & 4.286339 & 10.02572 \\
\hline Probability & 0.330263 & 0.386376 & 0.117283 & 0.006652 \\
\hline Sum & $4.52 \mathrm{E}+11$ & $3.64 \mathrm{E}+11$ & $1.15 \mathrm{E}+11$ & $3.80 \mathrm{E}+11$ \\
\hline Sum Sq. Dev. & $1.41 \mathrm{E}+22$ & $9.25 \mathrm{E}+21$ & $9.76 \mathrm{E}+20$ & $8.13 E+21$ \\
\hline Observations & 15 & 15 & 15 & 15 \\
\hline
\end{tabular}

Source: Authors (2018)

Description: * value is not in the form of logarithms

Based on the descriptive statistics of 15 observations, the highest value of zakat fund receipts was Rp97,637,657,910, the lowest was Rp296,086,166, and the average was Rp30,120,218,838. For zakat fund distribution, the highest value was Rp67,727,019,807, the lowest value was Rp99,895,146, and the average was 
Rp24,259,187,333. The highest operating expense value was Rp29,035,736,360 and the lowest was Rp150,644,968, with an average of $\mathrm{Rp} 7,670,746,281$. The highest value of total assets was Rp92,761,717,010, while the lowest was Rp472,729,642, with an average of Rp25,326,915,062.

\section{Regression Results}

The regression estimation method of this study used OLS and was processed with EViews 6.1. The estimation results of the OLS model for the dependent variable of zakat fund receipts showed an R-Square value of 0.986849 or 98.68 percent. This means that the percentage of the influence of operational expenses and total assets on the receipt of zakat funds as a dependent variable was 98.68 percent, or variations of independent variables used in the model were able to explain 98.68 percent of the dependent variable, while the remaining 1.32 percent was influenced or described by another variable beyond the estimation model.

As for the distribution of zakat funds, there was a relatively high R-Square value of 0.975392 or 97.54 percent. This means that the percentage of the effect of the operational expenses and total assets on the distribution of zakat funds as the dependent variable was 97.54 percent, or the variation of independent variables used in the model was able to explain 97.54 percent of the dependent variable, while the remaining 2.46 percent was affected or explained by other variables beyond the model estimation.

The estimation model was used for further processing with Frontier 4.1 to find the efficiency score produced by BAZNAS for the management of zakat funds. The efficiency score was also estimated by the maximum-likelihood estimation for the technical effect of the OLS model used. Estimated stochastic frontier model results with OLS and MLE differed slightly. There was a variable that had a significant effect on the OLS estimation model, but no significant effect on the MLE estimation model. The complete results of the OLS and MLE estimates are described in Table 2, as follows:

Table 2 OLS and MLE Regression Results

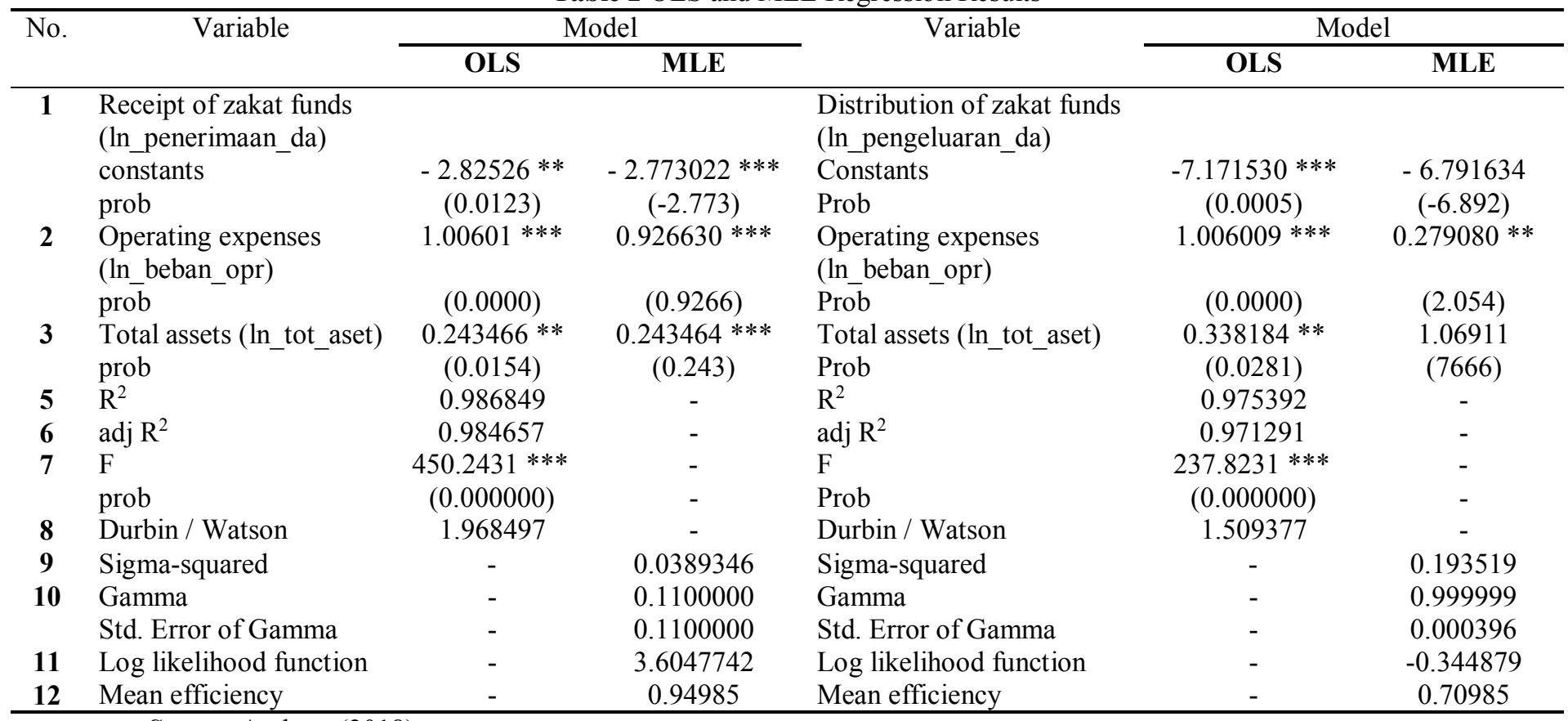

Source: Authors (2018)

Description: * Significant at 10 percent 
** Significant at 5 percent

*** Significant at 1 percent

\section{Receipt of Zakat Funds}

Based on the results shown in Table 2, the relationship between BAZNAS operational expenses and the total assets of the receipt of zakat funds, from 2002 to 2016, was analyzed using the following equation:

ln penerimaan_da $a_{t}=-2.77+0.927$ ln_beban_opr $\mathrm{t}_{\mathrm{t}}+0 . \overline{2} 431 \mathrm{ln}$ tot_aset $\mathrm{t}_{\mathrm{t}}+\mathrm{U}_{\mathrm{t}}-\mathrm{V}_{\mathrm{t}}$

Based on the results of the maximum likelihood estimate of the value of the SFA approach processed by Frontier 4.1, the obtained models had a gamma value of 0.999999 , with a standard error of 0.1100000 . The value of gamma coefficients close to one indicated that the variation of the error was more influenced by other random factors. The results of this gamma coefficient indicated that random factors other than independent variables and technical inefficiency dominated the variation of error. To determine the level of significance of the variables, t-ratios were compared with t-tables using the two-tailed test, with the following results:

The operational expenses variable had a positive and significant effect on the receipt of zakat funds. The results of the two-tailed statistical test demonstrated a variable operating expenses value smaller than df 13, at one percent significance level, which indicated the value of 3.01228. Thus, it can be concluded that operating expenses significantly influenced the receipt of zakat. A direct relationship between operating expenses and receipt of zakat can be seen from the value of the coefficient 0.926630 . From this figure, it was interpreted that the relationship between operating expenses and receipt of zakat was a one-way relationship (positive) because if the operating expenses increased by one percent, the value of zakat fund receipts would have increased by 0.927 percent, ceteris paribus.

The total asset variable had a positive and significant effect on zakat fund receipts. The statistical results of twotailed variables of total assets were smaller than df 13, at a one percent level of significance, which indicated the value of 3.01228. Thus, it was concluded that total assets had a significant effect on zakat fund receipts. The relationship between the variable of total assets and the receipt of zakat funds could be seen from the coefficient value of 0.243464 . It was interpreted from this figure that the relationship between total assets and the receipt of zakat funds was a one-way relationship (positive) because if total assets increased by one percent then the value of zakat fund receipts would have increased by 0.243 percent, ceteris paribus.

\section{Distribution of Zakat Funds}

Based on the results shown in Table 2, the relationship between BAZNAS operational expenses and the total assets of the distribution of zakat funds, from 2002 to 2016, was analyzed using the following equation:

$$
\begin{gathered}
\ln \_ \text {pengeluaran_dat }=-6.79+0.279 \\
\ln \_ \text {beban_opr }+1.069 \text { ln_tot_aset } t_{t}+U_{t^{-}} V_{t}
\end{gathered}
$$

Based on the result of maximum likelihood value estimation with an SFA approach that was processed using Frontier 4.1, we achieved the model with a gamma value equal to 0.1100000 with standard error 0.000396. A value of the gamma coefficient less than one indicates that the variation of the error is more influenced by other random factors. The results of this gamma coefficient showed that the random factor, in addition to independent variables 
and technical inefficiency, dominated the variation of error. The level of significance of the variables was determined by comparing t-ratios with t-tables using the two-tailed test, with the following results:

The operating expenses variable had a positive and significant effect on the distribution of zakat funds. The statistical results of the two-tailed operating expense value was smaller than of 13 , at the significance level of five percent, which indicated the value of 2.160371. Thus, it can be concluded that operating expenses significantly affected the distribution of zakat funds. A direct relationship between variable operating expenses and the distribution of zakat funds was demonstrated by the coefficient value of 0.279080 . From this figure, it was interpreted that the relationship between operating expenses and the distribution of zakat funds was a one-way relationship (positive) because if the operating expenses increased by one percent, the value of the distribution of zakat funds would have increased by 0.279 percent, ceteris paribus.

The total asset variable had a positive and not significant effect on the distribution of zakat funds. The statistical results of the two-tailed variable of total assets was larger than $\mathrm{df} 13$ at a significance level of ten percent, indicating a value of 1.77093 . Thus, it was concluded that total assets had no significant effect on the distribution of zakat funds.

\section{Measurement of BAZNAS's Technical Efficiency on Receipt of Zakat Funds}

Following the regression estimation, Table 3 and Figure 1 demonstrate the complete results of the measurement of BAZNAS's technical efficiency score for zakat fund receipts. The measurement of efficiency used the parametric method, resulting in a technical efficiency score on a scale of 0 1. The results that have a score closer to one indicate that BAZNAS operates more efficiently on the receipt of zakat funds, and vice versa.

Table 3 BAZNAS's Technical Efficiency Scores, 2002-2016 (percent)

\begin{tabular}{ccc}
\hline Year & Technical Efficiency & Technical Inefficiency \\
\hline 2002 & 0.9513 & 0.0487 \\
2003 & 0.9405 & 0.0595 \\
2004 & 0.9550 & 0.0450 \\
2005 & 0.9447 & 0.0553 \\
2006 & 0.9490 & 0.0510 \\
2007 & 0.9401 & 0.0599 \\
2008 & 0.9592 & 0.0408 \\
2009 & 0.9617 & 0.0383 \\
2010 & 0.9424 & 0.0576 \\
2011 & 0.9535 & 0.0465 \\
2012 & 0.9586 & 0.0414 \\
2013 & 0.9522 & 0.0478 \\
2014 & 0.9550 & 0.0450 \\
2015 & 0.9500 & 0.0500 \\
2016 & 0.9345 & 0.0655 \\
\hline \multicolumn{2}{c}{ Source: Authors (2018) }
\end{tabular}

Source: Authors (2018) 


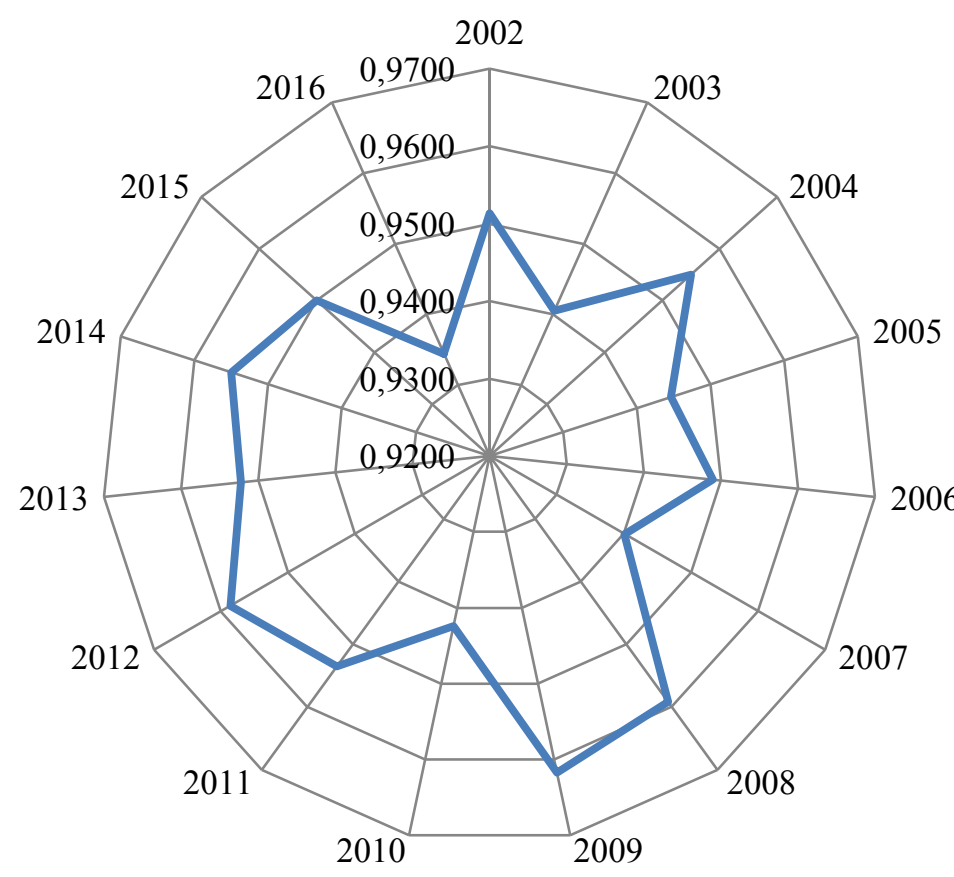

Technical Efficiency

Source: Authors (2018)

Figure 1 BAZNAS's Technical Efficiency, 2002-2016 (percent)

The calculations of the scores for technical efficiency of zakat fund receipts indicated that during the period range of the research, 2002-2016, there was no value with a perfect efficiency score of one. The imbalance in the BAZNAS efficiency scores for 2002-2016 regarding zakat fund receipts (see Figure 2) was seen in the range of technical efficiency scores, where a maximum value of 96.17 percent (2009) and a minimum of 93.45 percent (2016) were obtained. The technical efficiency score over the period of the study fluctuated and there remained a period of study (2016) which indicated that BAZNAS operations regarding zakat fund receipts carried an average technical efficiency score. When viewed as an aggregate, BAZNAS's technical efficiency regarding zakat fund receipts amounted to 94.98 percent, which means that 5.02 percent of the technical inefficiency of BAZNAS management can be optimized to achieve perfect efficiency. 


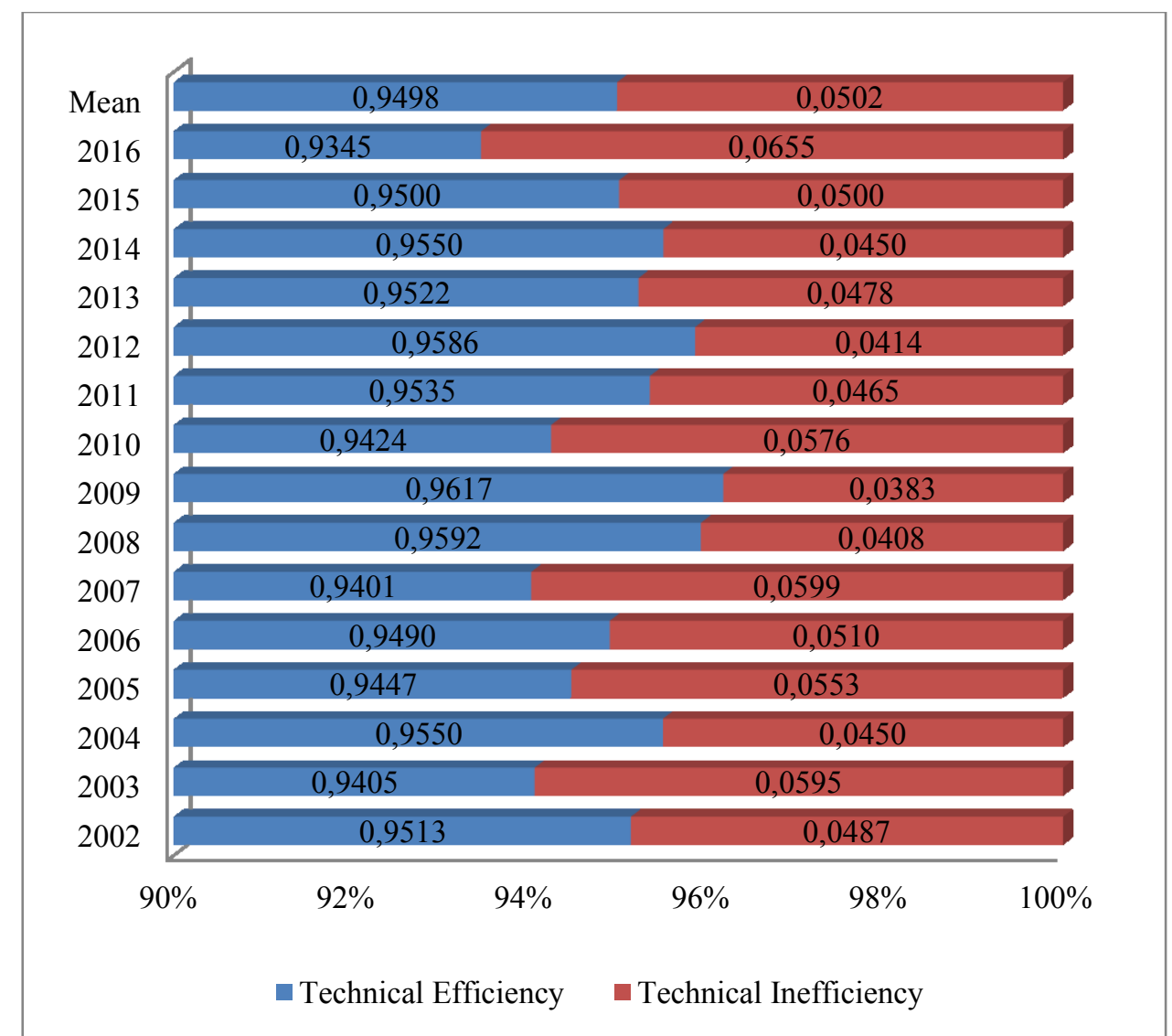

Source: Authors (2018)

Figure 2 Average Score for Technical Efficiency and Technical Inefficiency Regarding Receipt of Zakat Funds

After obtaining the results of the for the receipt of the zakat funds, which technical efficiency score, we found the consisted of a minimum value, maximum descriptive statistics on the results of the value, average, and standard deviation. technical efficiency calculation (see Table 4)

Table 4 Descriptive Statistics SFA Efficiency Values

\begin{tabular}{ccccc}
\hline & Min & Max & Mean & Std. deviation \\
\hline Efficiency & 0.9345 & 0.9617 & 0.9498 & 0.00792 \\
\hline Source: Authors (2018) & & &
\end{tabular}

The average technical efficiency value was 0.9498 , which means that the technical efficiency of BAZNAS between 2002 and 2016 reached 94.98 percent. In other words, there was still 5.02 percent of opportunities that could have been optimized to achieve the most efficient operational level. The most efficient period for
BAZNAS regarding the management of zakat fund receipts was found in 2009 , with a technical efficiency score of 96.17 percent, while the period found to be the most inefficient was2013 with the technical efficiency value of 93.45 percent. The technical efficiency value distribution is described in Table 5 below:

Table 5 Distribution of Technical Efficiency Value

\begin{tabular}{cccc}
\hline Efficiency Value & Frequency & Percentage & Category \\
\hline NTE $<\mathbf{0 . 9 4 2 4}$ & 3 & 20 & Not efficient \\
$\mathbf{0 . 9 4 2 4} \leq$ NTE $<\mathbf{0 . 9 5 0 3}$ & 4 & 26.67 & Less efficient \\
\hline
\end{tabular}




\begin{tabular}{cccc}
\hline NTE $\leq \mathbf{0 . 9 5 0 3}<\mathbf{0 . 9 6 2 9}$ & 7 & 46.67 & Quite efficient \\
NTE $\geq \mathbf{0 . 9 6 2 9}$ & 1 & 6.67 & Efficient \\
TOTAL & $\mathbf{2 7}$ & $\mathbf{1 0 0}$ & \\
\hline
\end{tabular}

Source: Authors (2018)

The grouping of the technical efficiency value was divided into four categories by using the percentile quartile \pm standard deviation equation, among others:

1. The value of technical efficiency < 0.9424 showed that in the receipt of zakat funds, BAZNAS was categorized as inefficient.

2. The technical efficiency value between 0.9424 and 0.9503 showed that in the receipt of zakat funds, BAZNAS was categorized as less efficient.

3. The technical efficiency values between 0.9503 and 0.9629 showed that in the receipt of zakat funds, BAZNAS was categorized as quite efficient.

4. The technical efficiency values $\geq 0.9629$ showed that in the receipt of zakat funds, BAZNAS was categorized as efficient.

Based on the classifications, there were three periods $(2003,2007$, and 2016) or 20 percent indicating that BAZNAS's management of zakat fund receipts was not efficient; four periods (2005, 2006, 2010, and 2015) or 26.67 percent where BAZNAS operated less efficiently in the management of zakat fund receipts; seven periods (2002, 2004, 2008, 2011, 2012, 2013, and 2014) or 46.67 percent that were categorized as quite efficient in the management of zakat fund receipts and; only one period (2009) or 6.67 percent that was declared efficient in the management of zakat fund receipts.

Measurement of BAZNAS's Technical Efficiency regarding Distribution of Zakat Funds

Following the regression estimation, Table 6 and Figure 3 present the complete results of the measurement of BAZNAS's technical efficiency scores for zakat fund distribution. The measurement of efficiency using the parametric method resulted in technical efficiency scores on a scale of $0-1$. The result of the SFA, which had a score of one, indicated that BAZNAS operates more efficiently in the distribution of zakat funds, and vice versa.

\begin{tabular}{ccc} 
Table 6 BAZNAS's Technical Efficiency Scores, 2002-2016 (percent) \\
\hline Year & Technical Efficiency & Technical inefficiency \\
\hline 2002 & 0.6097 & 0.3903 \\
2003 & 0.4015 & 0.5985 \\
2004 & 0.9895 & 0.0105 \\
2005 & 0.8583 & 0.1417 \\
2006 & 0.6746 & 0.3254 \\
2007 & 0.5896 & 0.4104 \\
2008 & 0.5707 & 0.4293 \\
2009 & 0.9990 & 0.0010 \\
2010 & 0.6779 & 0.3221 \\
2011 & 0.8032 & 0.1968 \\
2012 & 0.9690 & 0.0310 \\
2013 & 0.7526 & 0.2474 \\
2014 & 0.8114 & 0.1886 \\
2015 & 0.5991 & 0.4009 \\
\hline
\end{tabular}




\begin{tabular}{lll}
\hline 2016 & 0.3416 & 0.6584 \\
\hline Source: Authors (2018)
\end{tabular}

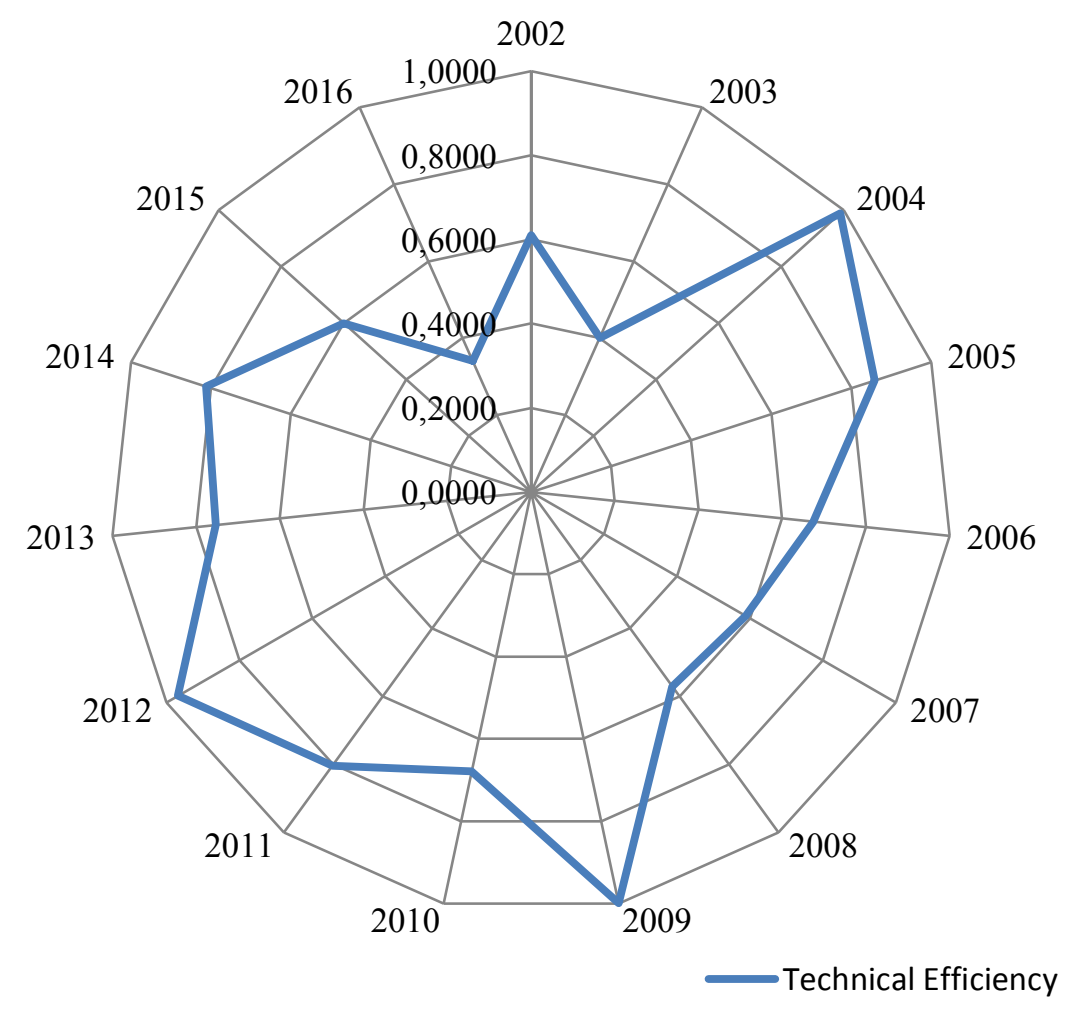

Source: Authors (2018)

Figure 3 BAZNAS's Technical Efficiency, 2002-2016 (percent)

The calculated scores for the technical efficiency of zakat fund distribution indicated that during the period range of the research, 2002-2016, there was no value of perfect efficiency with a score of one. There was an imbalance in BAZNAS efficiency scores for zakat fund distribution in 2002-2016 in (see Figure 3). This was found from the range of technical efficiency scores with a maximum value of 99.90 percent (2009) and a minimum of 34.16 percent (2016) that were obtained. The technical efficiency score fluctuated over the period of the study and there is still a period of the study which indicated that BAZNAS operations for zakat fund distribution is carried on average technical efficiency score. When viewed as an aggregate, BAZNAS's technical efficiency regarding zakat fund distribution amounted to 70.99 percent, which meant that there was a technical inefficiency of 29.01 percent in BAZNAS management that could have been optimized to achieve perfect efficiency. 


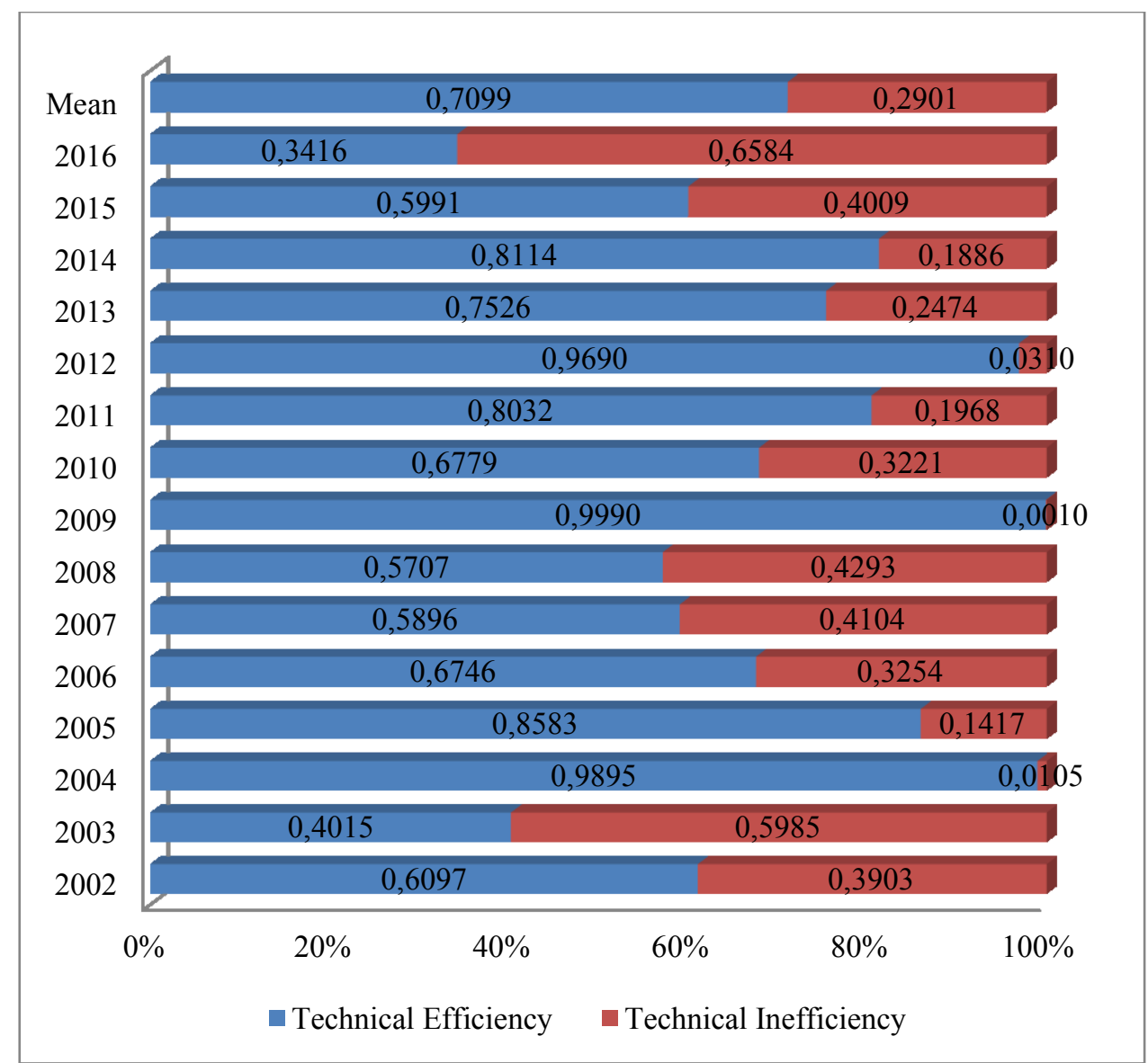

Source: Authors (2018)

Figure 4 Average Score for Technical Efficiency and Technical Inefficiency Regarding Distribution of Zakat Funds

After obtaining the results of the which consisted of a minimum value, technical efficiency score, we found the maximum value, average, and standard descriptive statistics on the results of the deviation on the distribution of zakat funds. technical efficiency calculation (see Table 7),

Table 7 Descriptive Statistics SFA Efficiency Values

\begin{tabular}{|c|c|c|c|c|}
\hline & Min & Max & Mean & Std. Deviation \\
\hline Efficiency & 0.3416 & 0.9990 & 0.7099 & 0.20016 \\
\hline
\end{tabular}

Source: Authors (2018)

The average technical efficiency value was 0.7099 , which meant that the technical efficiency of BAZNAS for the period 2002-2016 reached 70.99 percent. In other words, there was still 29.01 percent of opportunities that could have been optimized to achieve the most efficient operational level for the distribution of zakat funds. The most efficient period for BAZNAS on the management of zakat fund distribution was 2009 , with a score of 99.90 percent technical efficiency, while the most inefficient period was 2013 , with a technical efficiency value of only 34.16 percent. The technical efficiency value distribution is described in Table 8 below:

Table 8 Distribution of Technical Efficiency Value

\begin{tabular}{|c|c|c|c|}
\hline Efficiency Value & Frequency & Percentage & Category \\
\hline NTE $<0.5418$ & 2 & 13.33 & Not efficient \\
\hline $0.5418 \leq \mathrm{NTE}<0.7898$ & 7 & 46.67 & Less efficient \\
\hline NTE $\leq 0.7898<1.0585$ & 6 & 40 & Quite efficient \\
\hline
\end{tabular}




\begin{tabular}{|c|c|c|c|}
\hline NTE $\geq 1.0585$ & 0 & 0 & Efficient \\
\hline TOTAL & $\mathbf{2 7}$ & $\mathbf{1 0 0}$ & \\
\hline
\end{tabular}

Source: Authors (2018)

The grouping of technical efficiency value was divided into four categories by using percentile quartile \pm standard deviation equation, among others:

1. The technical efficiency value of $<$ 0.5418 showed that in the distribution of zakat funds, BAZNAS was categorized as inefficient.

2. The technical efficiency value between $0.5418-0.7898$ showed that in the distribution of zakat funds, BAZNAS was categorized as less efficient.

3. The technical efficiency values between $0.7898-1.0585$ showed that in the distribution of zakat funds, BAZNAS was categorized as quite efficient.

4. The technical efficiency values $\geq$ 1.0585 showed that in the distribution of zakat funds, BAZNAS was categorized as efficient.

Based on this classification, there were two periods (2003 and 2016), or 13.33 percent, which indicated that the management of zakat fund distribution by BAZNAS was not efficient; seven periods (2002, 2006, 2007, 2008, 2010, 2013, and 2015) or 26.67 percent where BAZNAS operated less efficiently in the management of zakat fund distribution; six periods (2004, 2005, 2009, 2011, 2014, and 2015) or 40 percent that were categorized as quite efficient in the management of zakat fund receipts; and no period that was declared efficient in the management of the distribution of zakat funds.

\section{CONCLUSION AND IMPLICATIONS}

\section{Conclusion}

Based on the analysis and discussion regarding the level of efficiency of the reception and distribution of zakat funds by BAZNAS in 2002-2016, the following conclusions can be drawn.

1. There is a difference of the estimation results between the OLS and MLE methods used in this study. Based on the OLS and MLE results, the operational expenses and total assets on the receipt of zakat funds either partially or wholly both show a positive and significant relationship, with only a different level of significance. The OLS and MLE results on the operational expenses for zakat fund distribution demonstrate a positive and significant relation, with a different level of significance. For total assets of zakat fund distribution, the results of OLS estimation are positive and significant, but based on MLE results, these are positive and insignificant.

2. The efficiency results regarding BAZNAS's average receipt of zakat for the period 2002-2016, using a parametric method (SFA), amount to 94.98 percent, which means that there is still a 5.02 percent chance that this could be optimized to achieve the highest operational efficiency level possible for BAZNAS. Historically, the technical efficiency of BAZNAS's zakat reception fluctuates, with the highest value occurring in 2009 with a technical efficiency value of 96.17 percent. As for BAZNAS's distribution of zakat funds, using a parametric method (SFA), this amounts to 70.99 percent. This means that there is still a 
29.01 percent chance that this could be optimized to improve the level of operational efficiency in the distribution of zakat funds by BAZNAS. The technical efficiency of BAZNAS has historically fluctuated, with the highest value occurring in 2009 with a score of 99.90 percent.

3. Regarding the acceptance period of zakat, BAZNAS has been most efficient in 2009 with a score of 96.17 , while the most efficient acceptance period of zakat funds is demonstrated in 2016 with a score of 93.45 percent. For the distribution of zakat funds, the most efficient period has been 2009, with a score of 99.90 percent, and the efficiency of the least efficient period, 2016 , is 34.16 percent.

\section{Recommendation}

Based on other research conclusions, there are certain implications and considerations that can be utilized in order to optimize the potential of BAZNAS so that the value of BAZNAS's efficiency in the management of zakat funds can be increased:

1. BAZNAS should pay more attention to the factors that affect the level of efficiency of the reception and distribution of zakat funds. Based on the results, it is known that the efficiency of the receipt of zakat funds is affected by operating expenses, while the efficiency of the distribution of zakat funds is influenced by total assets. Both of these variables can be focused on internally by BAZNAS in order to further improve efficiency.

2. The efficiency value of zakat fund distribution is relatively small compared with the efficiency of zakat reception, which is an area that BAZNAS could focus on when reevaluating operations, so as to achieve maximum efficiency. This could be done by setting better targets for the distribution of zakat funds to the most vulnerable citizens, and by ensuring transparency in the publication of financial statements in order to increase muzakki confidence.

\section{REFERENCES}

Aigner, D. J., Lovell, C. A. K.,\& Schmidt, P. (1977). Formulation and Estimation of Stochastic Frontier Production Models. Journal of Econometrics, 6, 21-37.

Al Parisi, S. (2017). Level of Efficiency and Productivity of Zakat Institutions in Indonesia. Journal of Business and Management Volume, 7(1), 63-72.

Archer, T. S. (2010). The Efficiency Theory: Improving Society by Eliminating Wasteful Programs, Restructuring the Economy, and Fixing Education. New York: CreateSpace Independent Publishing Platform. Retrieved from

http://www.theefficiencytheory.co $\mathrm{m} /$ The_Efficiency_Theory.pdf

Ariff, M., \& Viverita. (2011). Efficiency Measurement and Determinants of Indonesian Bank Efficiency. Paper to the Academy of Finance Service, $1-20$.

Battese, G. E. (1992). Frontier Production Functions and Technical Efficiency: A Survey of Empirical Applications in Agricultural Economics. Agricultural Economics, 7, 185-205.

Battese, G. E., \& Coelli, T. J. (1995). A Model for Technical Inefficiency Effects in a Stochastic Frontier Production Function for Data Panel. Empirical Economics,20, 325-332.

Bauer, P. W., Berger, A. N., Ferrier, G. D., \& Humphrey, D. B. (1998). Consistency Conditions for Regulatory Analysis of Financial Institutions: A Comparison of Frontier Efficiency Methods (The 
Financial Services Working Paper, 02/97).

Beik, I. S. (2009). Kajian Empiris Peranan Zakat dalam Pengentasan Kemiskinan. Jakarta: Indonesian Magnificence of Zakat.

Berger, A. N., \& Humphrey, D. B. (1997). Efficiency of Financial Institutions: International Survey and Directions for Future Research. European Journal of Operational Research, 98, 175-212.

Berger, A. N., \& Mester, L.J. (1997). Inside the Back Box: What Explains the Differences in Efficiencies of Financial Institutions? Journal of Banking and Finance, 21(7), 895-947.

Bhattacharyya, A., \& Pal, S. (2013). Financial Reforms and Technical Efficiency in Indian Commercial Banking: A Generalized Stochastic Frontier Analysis. Review of Financial Economics, 22, 109-117.

Coelli, T. J., Rao, D. S. P., O’Donnell, C. J., \& Battese, G. E. (2005). An Introduction to Efficiency and Productivity Analysis. New York: Springer.

Dong, Y., Hamilton, R., \& Tippett, M. (2014). Cost Efficiency of the Chinese Banking Sector: A Comparison of Stochastic Frontier Analysis and Data Envelopment Analysis. Economic Modeling, 36, 298-308.

Fadhlullah, A. H. (2015). Efisiensi Bank Pembangunan Daerah: Pendeatan Stochastic Frontier. Signifikan, Jurnal Ekonomi, 4(1), 1-16.

Fahmi, I. (2012). Analisis Laporan Keuangan, Cetakan Ke-2. Bandung: Alfabeta.

Farrell, M. J. (1957). The Measurement of Productive Efficiency. Journal of the Royal Statistical Society, 120(3), 253-290.

Febriani, A., \& Zulfadin., R. (2003). Analisis Kinerja Bank Devisa dan Non Devisa Indonesia. Kajian
Ekonomi Dan Keuangan, 7(4), 3854.

Fries, S., \& Taci, A. (2005). Cost Efficiency of Banks in Transition: Evidence from 289 Banks in 15 Post-Communist Countries. Journal of Banking and Finance, 29, 55-81.

Hadad, M. D., Santoso, W., Mardanugraha, E., \& Illyas, D. (2003). Pendekatan Parametrik Untuk Efisiensi Perbankan Indonesia. Research Banking System. Jakarta: Bank Indonesia.

Hafidhuddin, D. (2002). Zakat Dalam Perekonomian Modern. Jakarta: Gema Insani Press.

Iqbal, Z., \& Mirakhor, A. (2008). An Introduction to Islamic Finance: Theory and Practice. Singapore: John Wiley \& Sons.

Kusnadi. (2000). Akuntansi Keuangan Menengah (Intermediate) (Prinsip, Prosedur, dan Metode). Malang: Universitas Brawijaya Press.

Lembaga Pengembangan Perbankan Indonesia, \& Bank Indonesia. (2015). Profil Bisnis Usaha Mikro, Kecil, menengah (UMKM). Jakarta. Retrieved from http://www.bi.go.id/id/umkm/penel itian/nasional/kajian/Documents/Pr ofilBisnisUMKM.pdf

Marpaung, F. F., \& Afriani, S.(2016). Strategi Pemasaran Pada PT. Indomarco Adi Prima Stock Point Gading Cempaka Non Pasar (SP. Gcnp) Bengkulu. Ekombis Review, 4(1), 12-23.

Meeusen, W., \& Broeck, J. van den. (1977). Efficiency Estimation from Cobb-Douglas Production Function with Composed Error. International Economic Review, $18,435-444$.

Mlima, A. P., \& Hjalmarsson, L. (2002). Measurement of Input and Output in the Banking Industry. Tanzanet Journal, 3(1), 12-22.

Muhammad, G. (2007). Potret Perbankan 
Syariah Indonesia Terkini: Kajian Kritis Perkembangan Perbankan Syariah. Yogyakarta: Biruni Press.

Nashihina, M., \& Harahap, L. (2014). The Analysis of the Efficiency of BPRS: Production Function Approach vs Financial Ratios Approach. Procedia -Social and Behavioral Sciences, 115, 188-197.

Nasution, F.R., \& Marlina, L. (2013). Pengaruh Biaya Operasional Terhadap Laba Bersih Pada Bank Swasta Nasional yang Terdaftar di Bursa Efek Indonesia Periode 2009-2011. Media Informasi Manajemen, 1(3), 1-11. Retrieved from https: //Jurnal.Usu.ac.id/Index.Php/Jmim/ Article/View/2331/Pdf

Nguyen, T. P., Thien, H. S. N., Roca, E., \& Sharma, P. (2016). Bank Reforms and Efficiency in Vietnamese Banks: Evidence Based on SFA and DEA. Applied Economics, 48(30), 2822-2835.

Nurhasanah, S., \& Lubis, D. (2017). Efisiensi Kinerja Baznas Bogor dan Sukabumi: Pendekatan Data Envelopment Analysis. Jurnal Akuntansi Dan Keuangan Islam, 5(2), 101-120.

Permono, I. S., \& Darmawan. (2000). Analisis Efisiensi Industri Perbankan Di Indonesia (Studi Kasus Bank-Bank Devisa di Indonesia Tahun 1991-1996). Jurnal Ekonomi Dan Bisnis Indonesia, 15(1).

Schmidt, P., \& Lovell, C. A. K. (1979). Estimating Technical and Allocative Inefficiency Relative to Stochastic Production and Cost Frontiers. Journal of Econometrics, 9, 343-366.

Scout, A. B. (2011). Assessing Profit Efficiency of Islamic Banks in Indonesia: An Intermediation Approach. Journal of Economics, Business and Accountancy Ventura, 14(1), 31-42.
Silkman, R.H. (1986). Measuring Efficiency: An Assessment of Data Envelopment Analysis. San Francisco, USA: Jossey-Bass Inc Pub.

Tahir, M. I., \& Haron, S. (2008). Technical Efficiency of the Malaysian Commercial Banks: AStochastic Frontier Approach. Banks and Bank Systems, 3(4), 6572.

Zeller, M., \& Meyer, R. L. (2002). The Triangle of Microfinance: Financial Sustainability, Outreach, and Impact. Washington, DC:International Food Policy Res Inst Intl.

Zuhroh, I., Ismail, M., \& Maskie., G. (2015). The Cost Efficiency of Islamic Banks in Indonesia:A Stochastic Frontier Analysis. Procedia -Social and Behavioral Sciences, 211, 1122-1131.

Risanda A. Budiantoro
Airlangga University
Indonesia
risanda.abe@gmail.com
Faishol Luthfi
Airlangga University
Indonesia
isho12107@gmail.com
Sri Herianingrum
Airlangga University
Indonesia
sriheria@gmail.com

Airlangga University

Indonesia

risanda.abe@gmail.com

Faishol Luthfi

Airlangga University

Indonesia

ishol2107@gmail.com

Sri Herianingrum

Indonesia

sriheria@gmail.com 